\title{
Giant Plagioclase Basalts from Northeastern Deccan Volcanic Province, India: Implications for Their Origin and Petrogenetic Significance
}

\author{
Reddy V. R. Talusani ${ }^{1,2}$ \\ ${ }^{1}$ Earth Sciences, University of New England, Armidale, Australia \\ ${ }^{2}$ Department of Earth and Planetary Sciences, Macquarie University, Sydney, Australia \\ Email: vtalusan@hotmail.com
}

Received August 2, 2012; revised September 2, 2012; accepted October 1, 2012

\begin{abstract}
The giant plagioclase basalts (GPBs) with plagioclase phenocrysts that reach up to $3 \mathrm{~cm}$ in length are found near Jabalpur in the northeastern part of the Deccan Volcanic Province (DVP). The thickness of the basalt flow (flow 6) that contains the GPBs is $\sim 20 \mathrm{~m}$. Plagioclase phenocysts $\left(\mathrm{An}_{58}-\mathrm{An}_{64}\right)$ in the GPBs display many features of magma mixing (e.g., resorption, reverse zoning). Of the nine flows in the Jabalpur section, the GPBs (flow 6) with lowest Mg\#s (38 43) and $\mathrm{MgO}$ (4.16 - $5.08 \mathrm{wt} \%), \mathrm{Ni}$ and $\mathrm{Cr}$ abundances are the most evolved compositions. In addition, these GPBs have highest abundances of incompatible elements $\left(\mathrm{TiO}_{2}, \mathrm{P}_{2} \mathrm{O}_{5}, \mathrm{Nb}, \mathrm{Zr}, \mathrm{Sr}\right.$ and $\left.\mathrm{Ba}\right)$. The GPBs are compositionally similar to the well-studied Mahabaleshwar lavas of the western DVP. This new occurrence of GPBs has implications for existence of local crustal magma chambers, feeders and vents in the northeastern part of the DVP.
\end{abstract}

Keywords: Giant Plagioclase Basalt; Crustal Magma Chamber; Jabalpur; Deccan Volcanic Province; India

\section{Introduction}

The Deccan Volcanic Province (DVP) comprises vast thickness of laterally extensive basaltic flows that presently cover an area of about $500,000 \mathrm{~km}^{2}$ of west-central India (Figure 1). These lavas are near-horizontal and the exposed thickness is about $2000 \mathrm{~m}$. The estimated maximum thickness is about $4000 \mathrm{~m}$ [1] and the volume is 1.5 $\times 10^{6} \mathrm{~km}^{3}$ [2]. The bulk of the sequence of the DVP was erupted at Cretaceous-Tertiary boundary, $66 \mathrm{Ma}$ ago, over a short time span of one million years [3,4]. Although the DVP comprises predominantly tholeiitic basalts, it contains minor volumes of alkali basalts and various more evolved rocks.

During the past two decades considerable work has been done in chemical stratigraphy, petrology and geochemistry of the Deccan basalts in the western part of the DVP [5-13]. Relatively, much less is known about the central and eastern portions of the DVP $[11,14]$.

The giant plagioclase basalts (GPBs) occur both in continental and oceanic basalts. Their chemical and mineralogical compositions give insights into the processes that occur in crustal magma chambers (e.g., magma mixing and fractionation). Petrologically GPBs are an important component of the DVP. They were previously reported from the western Deccan [7,9,12,15]. However, until now there has been no information about GPBs from eastern or northeastern DVP. This paper reports a new occurrence of GPBs in the northeastern part of the DVP and presents mineralogical and chemical compositions.

The Jabalpur section studied is located SW of Jabalpur city in the northeastern part of the DVP (Figure 1). Field sampling was done several years ago while the author was working with the Geological Survey of India. The total thickness of nine basalt flows recognized at Jabalpur is about $170 \mathrm{~m}$. Of these nine flows, one flow (flow 6) contains GPBs. This flow has parts of the magma rich in plagioclase megacrysts. This area provides a unique opportunity to study GPBs in the northeastern part of the DVP. This short contribution focuses on the composition and petrogenetic significance of GPBs. The mineral chemistry and geochemistry of all the nine basaltic flows of this area will be presented in a separate full paper.

\section{Petrography and Mineral Chemistry}

The Jabalpur basalts are sparsely to moderately phyric ( 10 - 30 vol\% phenocrysts) with phenocrysts of plagioclase $\left(A n_{59}-A n_{70}\right)$, subordinate augite and rare olivine. The GPBs (flow 6) contain large (0.5 - $3 \mathrm{~cm}$ long) phenocrysts of plagioclase $\left(A n_{58}-A n_{64}\right)($ Figure 2) in a fine grained matrix consisting of plagioclase, augite, Fe-Ti oxide minerals and glass. Mineral compositions were ob- 


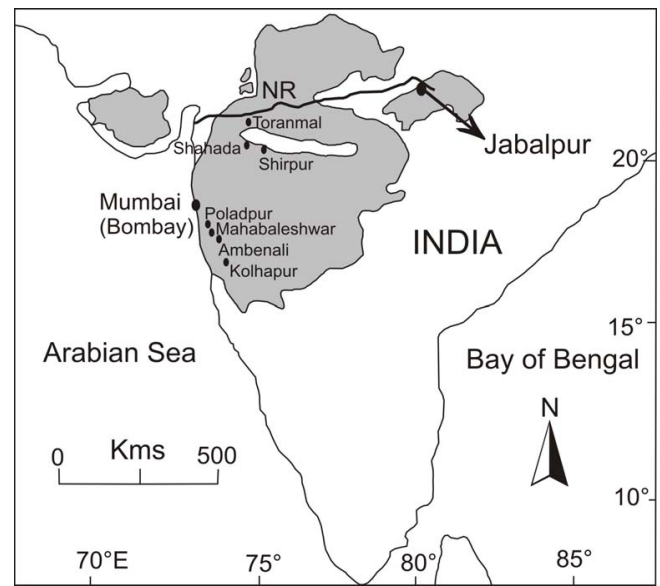

Figure 1. Map of India showing the deccan volcanic province (grey), important locations mentioned in the text and area of present study (Jabalpur). NR is the Narmada River.

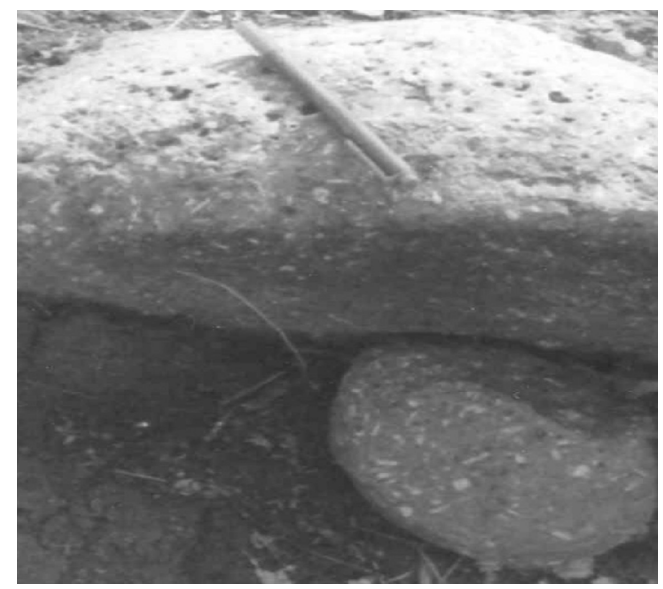

Figure 2. Field photograph of the giant plagioclase basalt from Jabalpur, northeastern Deccan volcanic province. The length of plagioclase phenocrysts reach up to $3 \mathrm{~cm}$.

tained using a JEOL JSM-5800LV scanning electron microscope (SEM) fitted with an Oxford Link ISIS energydispersive spectroscopy (EDS) system at the University of New England, Australia.

The plagioclase phenorysts display normal zoning and corroded borders and contain abundant, small post-crystallization melt inclusions. Also included within large plagioclase grains are small rounded grains of plagioclase with different compositions (up to three generations). Some plagioclase crystals show resorption and reverse zoning. Single crystals show core to rim variations of up to $10 \%$ An. All these disequilibrium features in the GPBs reflect magma mixing, recharge and complex convection effects in a magma chamber $[16,17]$.

\section{Geochemistry}

Major and trace elements were determined on glass discs and powder pellets respectively by X-ray fluorescence
(XRF) at the University of New England using standard methods. REE were determined by ICP-MS at Australian Laboratory Services, Brisbane. Whole rock data are presented in Table 1. Major elements are normalized to total on a volatile-free basis.

Of the nine flows in the Jabalpur section, the GPBs from flow 6 have the most evolved compositions with lowest Mg\#s (38 - 43) and MgO (4.16 - $5.08 \mathrm{wt} \%)$, Ni (28 - 48 ppm) and $\mathrm{Cr}$ (70 - 102 ppm) abundances. Also, they have the highest abundances of incompatible elements $\left(\mathrm{TiO}_{2}: 2.72-3.10 \mathrm{wt} \%, \mathrm{P}_{2} \mathrm{O}_{5}: 0.30-0.34 \mathrm{wt} \%, \mathrm{Nb}\right.$ : 15 - 19 ppm, Zr: 162 - 194 ppm, Sr: 278 - 365 ppm, and Ba: 175 - 235 ppm). The GPBs contrast sharply with the less evolved underlying and overlying flows by their mineralogical and chemical composition. These data highlight the compositional variation of the basalt flows in this part of the DVP. The compositional variation within flow 6 where the GPBs occur is larger than in any other less evolved flows of this study in the Jabalpur section.

Primitive mantle normalized incompatible trace element concentrations of the Jabalpur samples have been plotted as multi-element patterns in Figure 3. The variation in between samples is minor and the patterns are broadly similar. Mobile trace elements like $\mathrm{Rb}, \mathrm{Ba}$, Th and $\mathrm{Sr}$ are all similarly elevated or depleted. On the REE diagram (Figure 4), all the Jabalpur basalts plotted show a parallel nature of pattern with small negative Eu anomalies. All samples are moderately enriched in light-REE $[\mathrm{Ce} / \mathrm{Yb}]_{\mathrm{n}}=3.00-3.14$.

\section{Discussion}

The GPBs are important from petrogenetic point of view. Various disequilibrium features in the GPBs of Jabalpur reflect magma mixing, complex convection effects and recharge in a shallow magma chamber. Mixing of primitive magma injected into evolving chambers is an important part of several models which explain mineral disequilibrium, magma mixing, and specific major and trace element trends [e.g., 17]. The presence of the GPBs in flow 6 near Jabalpur suggests existence of shallow level crustal magma chambers and sources of lavas locally in this part of the DVP. The GPBs, because of their high viscosity, may not have traveled long distances [e.g., 18] from the main sources in the western rim to the northeastern part of the DVP. Furthermore, there are no reported occurrences of GPBs outside the western part of the Deccan Province suggesting a local origin for flow 6 .

The Jabalpur basalts define a good correlation between $\mathrm{MgO}$ and most major and trace elements. The difference between GPBs and non-GPB flows on most plots (not shown) is a clear separation into two groups. Some of these variations can be explained by fractional crystallization model. Least squares major element modeling done using Igpet 2007 [19] software suggests about 36\% 
Table 1. Whole rock analyses of giant plagioclase basalts from Jabalpur.

\begin{tabular}{|c|c|c|c|c|c|c|c|c|}
\hline Sample & DTB 6 & DTB 6A & DTB 32 & ${ }^{*}$ DTB 33 & DTB 35 & ${ }^{\mathrm{a}}$ Avg & ${ }^{\mathrm{b}}$ Avg & ${ }^{*}$ DTB 37 \\
\hline $\mathrm{SiO}_{2}(\mathrm{wt} \%)$ & 49.59 & 48.48 & 49.85 & 48.75 & 48.41 & 49.02 & 49.33 & 49.28 \\
\hline $\mathrm{TiO}_{2}$ & 2.72 & 2.76 & 2.96 & 3.10 & 3.04 & 2.92 & 2.29 & 1.92 \\
\hline $\mathrm{Al}_{2} \mathrm{O}_{3}$ & 13.87 & 14.18 & 13.40 & 13.91 & 14.32 & 13.94 & 13.46 & 14.00 \\
\hline $\mathrm{Fe}_{2} \mathrm{O}_{3}(\mathrm{~T})$ & 15.50 & 15.44 & 15.27 & 15.64 & 14.99 & 15.37 & 14.47 & 13.28 \\
\hline $\mathrm{MnO}$ & 0.18 & 0.19 & 0.17 & 0.19 & 0.21 & 0.19 & 0.24 & 0.21 \\
\hline $\mathrm{MgO}$ & 5.08 & 4.77 & 4.61 & 4.16 & 4.32 & 4.59 & 6.40 & 7.43 \\
\hline $\mathrm{CaO}$ & 10.45 & 10.74 & 10.57 & 11.02 & 11.21 & 10.80 & 10.83 & 11.60 \\
\hline $\mathrm{Na}_{2} \mathrm{O}$ & 2.50 & 2.32 & 2.73 & 2.42 & 2.47 & 2.49 & 2.70 & 2.72 \\
\hline $\mathrm{K}_{2} \mathrm{O}$ & 0.17 & 0.38 & 0.22 & 0.31 & 0.29 & 0.28 & 0.26 & 0.16 \\
\hline $\mathrm{P}_{2} \mathrm{O}_{5}$ & 0.30 & 0.30 & 0.31 & 0.34 & 0.32 & 0.31 & 0.23 & 0.21 \\
\hline Total & 100.36 & 99.57 & 100.16 & 99.97 & 99.73 & 99.96 & 100.21 & 100.81 \\
\hline LOI & 2.31 & 2.29 & 1.87 & 1.50 & 2.52 & 2.10 & 1.95 & 2.05 \\
\hline${ }^{\mathrm{c}} \mathrm{Mg \#}$ & 43 & 42 & 41 & 38 & 40 & 41 & 51 & 57 \\
\hline \multicolumn{9}{|c|}{ Trace elements (ppm) } \\
\hline $\mathrm{Nb}$ & 17 & 15 & 16 & 19 & 18 & 17 & 11 & 8 \\
\hline $\mathrm{Zr}$ & 162 & 165 & 182 & 194 & 180 & 177 & 139 & 110 \\
\hline $\mathrm{Y}$ & 32 & 33 & 38 & 36 & 38 & 35 & 33 & 29 \\
\hline Sr & 305 & 365 & 278 & 309 & 331 & 318 & 219 & 223 \\
\hline $\mathrm{Rb}$ & 1 & 3 & 2 & 6 & 4 & 3 & 7 & 1 \\
\hline Th & 3 & 6 & 5 & 4 & 3 & 4 & 5 & 5 \\
\hline $\mathrm{Pb}$ & 2 & 3 & 4 & 3 & 4 & 3 & 5 & 4 \\
\hline Ga & 16 & 17 & 17 & 19 & 20 & 18 & 21 & 23 \\
\hline $\mathrm{Zn}$ & 107 & 101 & 99 & 110 & 113 & 106 & 115 & 98 \\
\hline $\mathrm{Cu}$ & 220 & 202 & 200 & 193 & 214 & 206 & 190 & 177 \\
\hline $\mathrm{Ni}$ & 48 & 42 & 31 & 28 & 36 & 37 & 67 & 96 \\
\hline $\mathrm{Cr}$ & 102 & 94 & 82 & 70 & 86 & 87 & 126 & 206 \\
\hline $\mathrm{Ba}$ & 187 & 235 & 194 & 175 & 205 & 199 & 109 & 77 \\
\hline V & 392 & 383 & 360 & 369 & 373 & 375 & 405 & 360 \\
\hline Sc & 29 & 26 & 23 & 28 & 30 & 27 & 39 & 55 \\
\hline \multicolumn{9}{|l|}{ REE (ppm) } \\
\hline $\mathrm{La}$ & 15.9 & & 18.2 & & 19.3 & 17.8 & 16.0 & 14.0 \\
\hline Ce & 35.9 & & 39.8 & & 42.6 & 39.4 & 35.8 & 31.0 \\
\hline $\operatorname{Pr}$ & 5.1 & & 5.6 & & 5.9 & 5.5 & 5.0 & 4.3 \\
\hline $\mathrm{Nd}$ & 22.5 & & 24.9 & & 26.6 & 24.7 & 22.0 & 18.8 \\
\hline $\mathrm{Sm}$ & 6.6 & & 7.3 & & 7.8 & 7.2 & 6.4 & 5.4 \\
\hline $\mathrm{Eu}$ & 2.02 & & 2.24 & & 2.37 & 2.21 & 2.01 & 1.71 \\
\hline Gd & 6.3 & & 6.8 & & 7.1 & 6.7 & 6.1 & 5.3 \\
\hline $\mathrm{Tb}$ & 1.03 & & 1.12 & & 1.17 & 1.11 & 1.00 & 0.86 \\
\hline Dy & 6.5 & & 7.2 & & 7.5 & 7.1 & 6.3 & 5.4 \\
\hline Ho & 1.34 & & 1.44 & & 1.52 & 1.43 & 1.30 & 1.12 \\
\hline Er & 3.68 & & 3.94 & & 4.13 & 3.92 & 3.54 & 3.09 \\
\hline $\mathrm{Tm}$ & 0.52 & & 0.55 & & 0.59 & 0.55 & 0.51 & 0.43 \\
\hline $\mathrm{Yb}$ & 3.09 & & 3.39 & & 3.54 & 3.34 & 2.95 & 2.48 \\
\hline $\mathrm{Lu}$ & 0.43 & & 0.49 & & 0.5 & 0.47 & 0.41 & 0.33 \\
\hline
\end{tabular}

${ }^{\mathrm{a}}$ Avg-Average of five GPB samples (major oxides and trace elements) \& average of 3 GPB samples (REE); ${ }^{\mathrm{b}} \mathrm{Avg}$-Average of 16 non-GPB samples from 8 flows (major oxides and trace elements) \& average of 8 non-GPB samples (REE); ${ }^{*}$ DTB 33 (GPB) and ${ }^{*}$ DTB 37 (non-GPB) are the most evolved and most primitive samples respectively of the Jabalpur section; ${ }^{\mathrm{C}} \mathrm{Mg}$, calculated assuming $\mathrm{Fe}_{2} \mathrm{O}_{3} / \mathrm{FeO}=0.15$. 


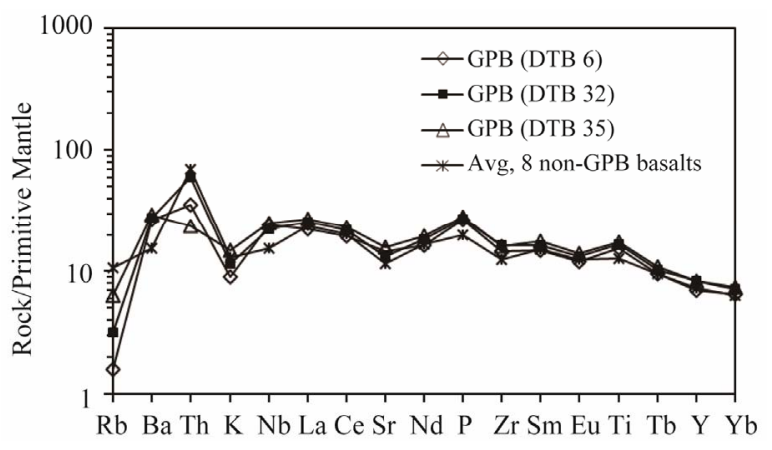

Figure 3. Multi-element plots for the Jabalpur GPBs and average of five samples from non-GPB flows normalized against the primitive mantle of McDonough et al., [21].

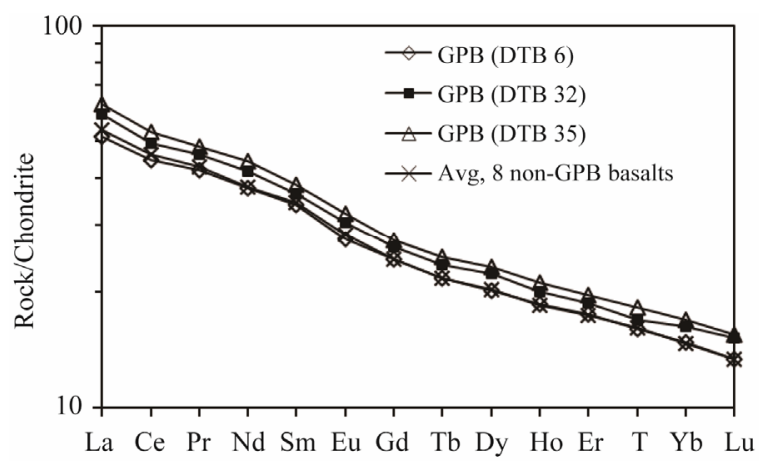

Figure 4. REE plots for the Jabalpur GPBs and average of five samples from non-GPB flows normalized against the chondrite of Boynton, [22].

of fractional crystallization for non-GPB flows. Variations in major elements of GPBs (Flow 6) cannot be reproduced successfully by this method. Major element variations in GPBs require the addition of a crustal contaminant into the system along with fractional crystallization to produce the observed trends.

During fractional crystallization of common silicate phases (e.g., plagioclase, pyroxene, olivine) the ratios of highly incompatible elements such as $\mathrm{Zr}, \mathrm{Y}$ and $\mathrm{Nb}$ will not vary dramatically. Variations in $\mathrm{Zr} / \mathrm{Nb}=17.29$ - 9.53, $\mathrm{Zr} / \mathrm{Y}=5.39-3.79$ and $\mathrm{Ba} / \mathrm{Zr}=1.51-0.21$ in the Jabalpur basalts are too large to be attributed simply to fractional crystallization processes. Such variations reflect heterogeneity in the source and/or magma mixing. Furthermore, low $\mathrm{Y} / \mathrm{Nb}$ ratios (average $=3.04$ and 2.08 for nonGPB flows and GPBs respectively) suggest crustal contamination was minimal, which would have influenced these element ratios [20].

Incompatible elements, including the REE exhibit (Figures 3 and 4) similar patterns. These similarities in chemical signatures between GPBs and non-GPB flows represent similar process of magma generation for these two groups of flows. Modeling calculations were carried out to quantitatively evaluate the source mineralogy and the amount of partial (batch) melting. A garnet lherzolite source [23] with a mode of 55\% olivine, 30\% orthopyroxene, $10 \%$ clinopyroxene and $5 \%$ garnet was used. To consider the possibility of shallower melting in the spinel zone modeling has also been done from melting of a spinel lherzolite with 5\% spinel instead of garnet (Figure 5). This partial melting modeling using the non-modal batch melting equation of Shaw, [24] suggests that lavas from the Jabalpur section were derived by about $6 \%$ $10 \%$ melting of peridotite containing no garnet. The primary magmas were derived from a relatively shallow mantle source.

Ambenali and Mahabaleshwar formations are the two well-studied lavas from the western DVP. The plot of $\mathrm{Ba} / \mathrm{Y}$ ratio against $\mathrm{Zr} / \mathrm{Nb}$ ratio for all the Jabalpur samples (Figure 6) reveals that most of the samples from the eight non-GPB flows of the Jabalpur section show affinity to the least contaminated Ambenali formation of the western DVP, whereas the GPBs (flow 6) are compositionally similar to the Mahabaleshwar formation of the western Deccan (average ratio of $\mathrm{Zr} / \mathrm{Y}=5.02-4.60$, $\mathrm{Zr} / \mathrm{Nb}=10.35-9.85, \mathrm{Ba} / \mathrm{Y}=5.62-5.83, \mathrm{TiO}_{2}=2.92$

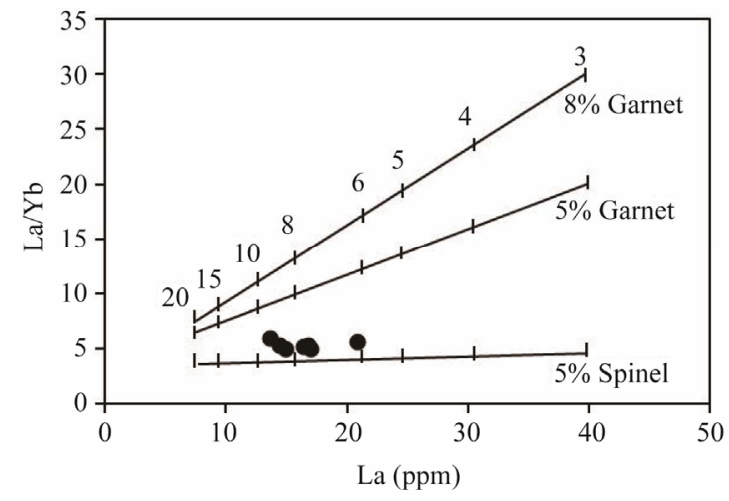

Figure 5. La versus La/Yb diagram showing the results of batch melting modeling of garent and spinel lherzolites. Numbers indicate percentage of melt fractions.

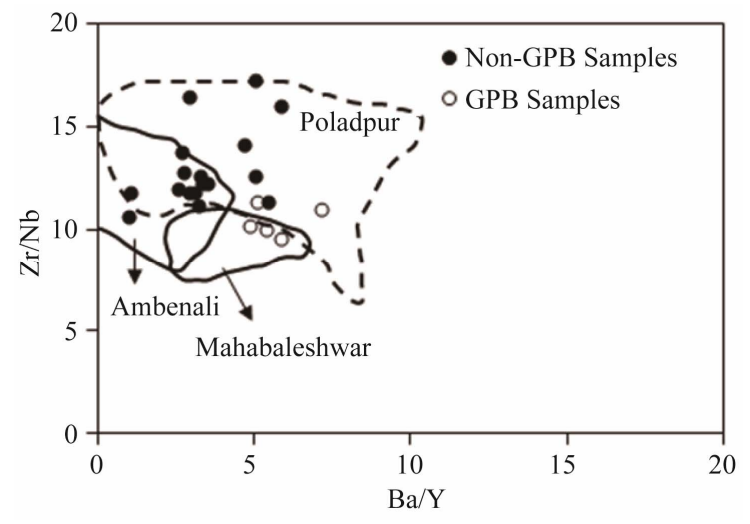

Figure 6. $\mathrm{Ba} / \mathrm{Y}$ versus $\mathrm{Zr} / \mathrm{Nb}$ in the Jabalpur basalts. Also shown are fields of Ambenali, Mahabaleshwar and Poladpur formations of the Wai subgroup from western DVP [6,7, 25]. 
wt $\%$ - 2.34 wt\%, Ba = 199 ppm - 175 ppm, Sr = 317 ppm - 283 ppm for the Jabalpur GPBs and the Maha-baleshwar lavas respectively. Mahabaleshwar values are from Lightfoot et al., [26]). However, compared to the Mahabaleshwar lavas, these GPBs are chemically more evolved with lower Mg\#s, and $\mathrm{MgO}, \mathrm{Ni}$ and $\mathrm{Cr}$ abundances, and higher concentrations of LILE (Sr, Ba) and HFSE $(\mathrm{Nb}, \mathrm{Zr})$. These compositional features suggest that the GPBs are the products of fractional crystallization of a parental magma similar to the Mahabaleshwar magma generated in this part of the DVP. Continuing work in the eastern and central portions of the DVP may lead to identification of more areas of GPBs and presence of local sub-volcanic crustal magma chambers, feeders and vents within the DVP.

\section{Conclusions}

The GPBs are the most evolved tholeiitic basalts found in the Jabalpur section of present study. They show many features of magma mixing (e.g., resorption, reverse zoning). The GPBs represent local subvolcanic crustal magma chambers and sources of lavas in the northeastern part of the DVP.

\section{Acknowledgements}

The manuscript was considerably improved by thorough review and constructive comments from Morihisa Hamada. Thanks to J. Bedford for XRF analyses and T. Swapna for word processing and drafting figures. Comments from journal reviewers improved the manuscript.

\section{REFERENCES}

[1] Z. X. Peng, J. J. Mahoney, P. R. Hooper, C. Harris and J. E. Beane, "A Role for Lower Continental Crust in the Flood Basalt Genesis? Isotopic and Incompatible Element Study of the Lower Six Formations of the Western Deccan Traps," Geochimica et Cosmochimica Acta, Vol. 58, No. 1, 1994, pp. 267-288.

doi:10.1016/0016-7037(94)90464-2

[2] O. Eldholm and M. F. Coffin, "Large Igneous Provinces and Plate Tectonics,” In: M. A. Richards, R. G. Gordon and R. D. Van Der Hilst, The History and Dynamics of Global Plate Motions. Geophysical Monographs, Amer Geophysical Union, Washington, 2000, pp. 309-326.

[3] R. A. Duncan and D. G. Pyle, "Rapid Eruption of the Deccan Flood Basalts at the Cretaceous/Tertiary Boundary,” Nature, Vol. 333, No. 6176, 1988, pp. 841-843. doi:10.1038/333841a0

[4] C. Hofmann, G. Feraud and V. Courtillot, " $39 \mathrm{Ar} /{ }^{40} \mathrm{Ar}$ Dating of Mineral Separates and Whole Rocks from the Western Ghats Lava Pile: Further Constraints on Duration and Age of the Deccan Traps," Earth and Planetary Science Letters, Vol. 180, No. 1-2, 2000, pp. 13-27. doi:10.1016/S0012-821X(00)00159-X
[5] J. J. Mahoney, J. D. Macdougall, G. W. Lugmair, A. V. Murali, M. Das and K. Gopalan, "Origin of the Deccan Trap Flows at Mahabaleshwar Inferred from Nd and $\mathrm{Sr}$ Isotopic and Chemical Evidence," Earth and Planetary Science Letters, Vol. 60, No. 1, 1982, pp. 47-60.

doi:10.1016/0012-821X(82)90019-X

[6] K. G. Cox and C. J. Hawkesworth, "Geochemical Stratigraphy of the Deccan Traps at Mahabaleshwar, Western Ghats, India, with Implications for Open System Magmatic Processes,” Journal of Petrology, Vol. 26, No. 2, 1985, pp. 355-377.

[7] J. E. Beane, C. A. Turner, P. R. Hooper, K. V. Subbarao and J. N. Walsh, "Stratigraphy, Composition and Form of the Deccan Basalts, Western Ghats, India," Bulletin of Volcanology, Vol. 48, No. 1, 1986, pp. 61-83. doi:10.1007/BF01073513

[8] G. Sen, "Mineralogy and Petrogenesis of the Deccan Trap lava Flows around Mahabaleshwar, India," Journal of Petrology, Vol. 27, No. 3, 1986, pp. 627-663.

[9] P. R. Hooper, K. V. Subba Rao and J. E. Beane, “The Giant Plagioclase Basalts (GPBs) of the Western Ghats, Deccan Traps," Memoir of the Geological Society of India, Vol. 10, 1988, pp. 135-144.

[10] L. Melluso, L. Beccaluva, P. Brotzu, A. Gregnanin, A. K. Gupta, L. Morbidelli and G. Traversa, "Constraints on the Mantle Sources of the Deccan Traps from the Petrology and Geochemistry of the Basalts of Gujarat State (Western India),” Journal of Petrology, Vol. 36, No. 5, 1995, pp. 1393-1432.

[11] Z. X. Peng, J. J. Mahoney, P. R. Hooper, J. D. Macdougall and P. Krishnamurthy, "Basalts of the Northeastern Deccan Traps, India: Isotopic and Elemental Geochemistry and Relation to Southwestern Deccan stratigrapy," Journal of Geophysical Research, Vol. 103, No. B12, 1998, pp. 29843-29865. doi:10.1029/98JB01514

[12] J. J. Mahoney, H. C. Sheth, D. Chandrasekharam and Z. X. Peng, "Geochemistry of Flood Basalts of the Toranmal Section, Northern Deccan Traps, India: Implications for Regional Deccan Stratigraphy,” Journal of Petrology, Vol. 41, No. 7, 2000, pp. 1099-1120. doi:10.1093/petrology/41.7.1099

[13] M. D. Higgins and D. Chandrasekharam, "Nature of Sub-Volcanic Magma Chambers, Deccan Province, India: Evidence from Quantitative Textural Analysis of Plagioclase Megacrysts in the Giant Plagioclase Basalts,” Journal of Petrology, Vol. 48, No. 5, 2007, pp. 885-900. doi:10.1093/petrology/egm005

[14] R. V. R. Talusani, "Bimodal Tholeiitic and Mildly Alkalic Basalts from Bhir Area, Central Deccan Volcanic Province, India: Geochemistry and petrogenesis,” Journal of Volcanology and Geothermal Research, Vol. 189, No. 3, 2010, pp. 278-290. doi:10.1016/j.jvolgeores.2009.11.019

[15] D. Chandrasekharam, J. J. Mahoney, H. C. Sheth and R. A. Duncan, "Elemental and Nd-Sr-Pb Isotope Geochemistry of Flows and Dikes from the Tapti Rift, Deccan Flood Basalt Province, India,” Journal of Volcanology and Geothermal Research, Vol. 93, No. 1-2, 1999, pp. 111-123. doi:10.1016/S0377-0273(99)00081-5 
[16] A. P. le Roex, F. A. Frey and S. H. Richardson, "Petrogenesis of Lavas from the AMAR Valley and Narrowgate Region of the FAMOUS Valley, $36^{\circ}-37^{\circ} \mathrm{N}$ on the Mid-Atlantic Ridge," Contributions to Mineralogy and Petrology, Vol. 124, No. 2, 1996, pp. 167-184. doi:10.1007/s004100050183

[17] H. Hansen and K. Grönvold, "Plagioclase Ultraphyric Basalts in Iceland: The Mush of the Rift," Journal of Volcanology and Geothermal Research, Vol. 98, 2000, pp. 1-32. doi:10.1016/S0377-0273(99)00189-4

[18] J. J. Mahoney, “Deccan Traps,” In: J. D. Macdougall, Ed., Continental Flood Basalts, Kluwer Academic Publishers, Norwell, 1988, pp. 151-194.

[19] M. Carr, “Igpet 2007 for Windows XP or Vista,” Terra Softa Inc, 2007.

[20] M. Wilson, “Igneous Petrogenesis,” Unwin Hyman, London, 1989. doi:10.1007/978-1-4020-6788-4

[21] W. F. McDonough, S. Sun, A. E. Ringwood, E. Jagoutz and A. W. Hofman, "K, Rb and Cs in the Earth and Moon and the Evolution of the Earth's Mantle," Geochimica et Cosmochimica Acta, Vol. 56, 1992, 1001-1012.
[22] W. V. Boynton, "Geochemistry of the Rare Earth Elements: Meteorite Studies,” In: P. Henderson, Ed., Rare Earth Element Geochemistry, Elsevier, Amsterdam, 1984, pp. 63-114.

[23] L. E. Borg, M. A. Clynne and T. A. Bullen, "The Variable Role of Slab-Derived Fluids in the Generation of a Suite of Primitive Calc-Alkaline Lavas from the Southernmost Cascades, California," Canadian Mineralogist, Vol. 35, 1997, pp. 425-452.

[24] D. M. Shaw, "Trace Element Fractionation during Anatexis,” Geochimica et Cosmochimica Acta, Vol. 34, No. 2, 1970, pp. 237-243. doi:10.1016/0016-7037(70)90009-8

[25] C. W. Devey and P. C. Lightfoot, "Volcanological and Tectonic Control of Stratigraphy and Structure in the Western Deccan Traps,” Bulletin of Volcanology, Vol. 48, No. 4, 1986, pp. 195-207. doi:10.1007/BF01087674

[26] P. C. Lightfoot, C. J. Hawkesworth, C. W. Devey, N. W. Rogers and P. W. C. Van Calsteren, "Source and Differentiation of Deccan Trap Lavas: Implications of Geochemical and Mineral Chemical Variations," Journal of Petrology, Vol. 31, No. 5, 1990, pp. 1165-1200. 